Kirja-arvio

\title{
Ikkunoita hulluuteen ja hulluustutkimukseen
}

Jäntti, Saara, Kirsi Heimonen, Sari Kuuva ja Annastiina Mäkilä (toim.). 2019. Hulluus ja kulttuurinen mielenterveystutkimus. Jyväskylä: Nykykulttuuri. 347 sivua.

\section{Anna Kinnunen}

$\mathrm{H}$ arva kirja on yhtä odotettu ja ajankohtainen kuin Hulluus ja kulttuurinen mielenterveystutkimus (2019). Henkilökohtaisesti olen odottanut sen ilmestymistä jo vuosia, aina siitä lähtien, kun sain tietää sen olevan tekeillä. Kun kirja keväällä 2019 ilmestyi, se ajoittui sopivasti yhteen oman, saman aihepiirin äärellä liikkuvan artikkeliväitöskirjani johdanto-osuuden kirjoittamisen kanssa. Tartuinkin teokseen suurella mielenkiinnolla, enkä varmasti ollut ainoa: keskustelu hulluuden ympärillä on viime vuosina lisääntynyt voimakkaasti sekä tieteessä että sen ulkopuolella, ja tämän keskustelun synnyttämään tarpeeseen kyseinen teos pyrkii osaltaan vastaamaan.

Saara Jäntin, Kirsi Heimosen, Sari Kuuvan ja Annastiina Mäkilän toimittama teos onkin ensimmäinen kotimainen artikkelikokoelma, joka paikantuu 2010-luvulla ajankoh-

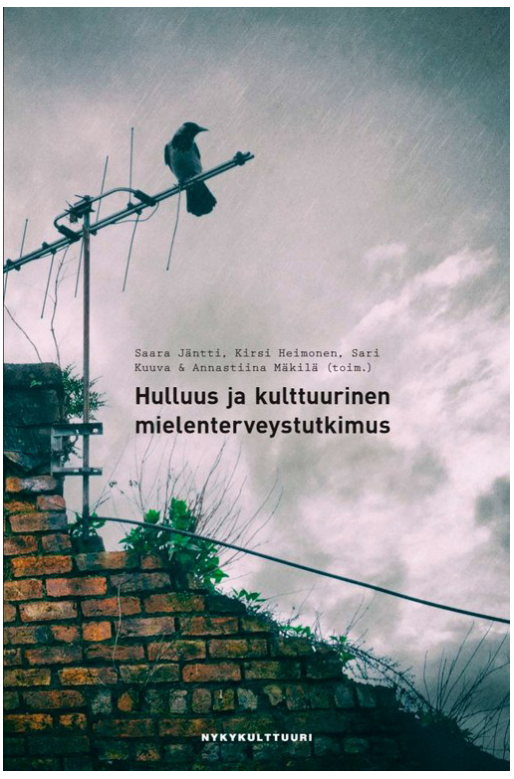
taistuneeseen kulttuuriseen mielenterveystutkimukseen ja hulluustutkimukseen (engl. Madness Studies ja/tai Mad Studies). Hulluus, joka jo itsessään on vaikea ja määrittelijäänsä pakeneva käsite, on teoksen toimittajille laaja "kattokäsite, jonka alla psykiatria diagnooseineen ja hoitokäytänteineen muodostaa yhden diskursiivisen viitekehyksen poikkeavuuden käsittelylle" (s. 9-10). Näin ollen hulluustutkimus on kiinnostunut niistä historiallisesti ja kulttuurisesti muuntuvista tavoista, joilla hulluudeksi mielletyt tilat ilmenevät ja joiden avulla niitä käsitellään ja nimetään.

Teoksella on useita sekä tieteellisesti että inhimillisesti merkittäviä päämääriä. Yhtäältä se pyrkii esittelemään uusinta suomalaista hulluustutkimusta, johon liittyvään keskusteluun on viime vuosina osallistuttu myös folkloristiikan ja perinteentutkimuksen aloilla sekä Eloren sivuilla (esim. Hulluus-teemanumero 2016; Kinnunen 2017; Maanmieli 2019). 
Toisaalta hulluuden tarkastelu nivoutuu vääjäämättä kärsimyksen ja poikkeavuuden kokemuksiin ja kokijoihin, siis ihmisiin, joita esimerkiksi psyykkinen sairaus suoraan tai välillisesti koskettaa. Jotta mielenterveysongelmien kanssa elävien ihmisten tarpeet ja kokemusmaailma sekä psykiatrinen apu kohtaisivat toisensa mahdollisimman ristiriidattomasti, tarvitaan hulluustutkimuksen tuottamaa ymmärrystä tavoista ja diskursseista, joiden varaan käsitykset hulluudesta rakentuvat. Lisäksi teoksessa pyritään pohtimaan, olisiko mielenterveysongelmia mahdollista käsitellä ja merkityksellistää myös uudenlaisten ja yllättävienkin tapojen, kuten esimerkiksi taiteen avulla. Tällainen pohdinta ja uusien näkökulmien etsintä on tärkeää, sillä psykiatria ei kykene auttamaan kaikkia, eikä psyykkistä kärsimystä voida lopullisesti poistaa. (S. 28.)

\section{Kun ikkuna vaihtuu, näkymä hulluuteen muuttuu}

Hulluus ja kulttuurinen mielenterveystutkimus on monitieteinen teos, mutta siinä painottuvat historian ja taiteen näkökulmat. Teos sisältää 11 artikkelia, toimittajien esipuheen sekä jälkisanat. Artikkelit on ryhmitelty neljäksi kokonaisuudeksi: Hulluus sairaaloissa, Hulluus kodeissa, Hulluus yhteisöissä ja Hulluus kielessä. Samaankin osioon peräjälkeen sijoitetut artikkelit ovat kuitenkin miltei poikkeuksetta hyvinkin erityyppisiä niin näkökulmansa kuin metodinsakin puolesta. Tämä on koko teosta läpäisevä, leimallinen piirre: sen artikkeleista jokainen avaa yhdenlaisen ikkunan hulluuteen, ja kun lukija kurkistaa seuraavan artikkelin tarjoamasta ikkunasta, silmien eteen avautuva näkymä on usein tyystin toisenlainen.

Jo teoksen avaavat Sari Kuuvan ja Anu Rissasen artikkelit tarjoavat hulluuteen kaksi keskenään hyvin erityyppistä ikkunaa. Kuuvan tutkimuskohteena ovat "hulluuden säikeet" Edward Munchin (1863-1944) elämässä ja taiteessa. Aineistonaan hän käyttää Munchin taidetta ja tekstejä sekä aiheeseen liittyvää aikaisempaa tutkimusta. Artikkeli sopii erinomaisesti teoksen ensimmäiseksi artikkeliksi, sillä se avaa hulluuden jo sinällään problemaattista käsitettä. Kuuva käsitteellistää hulluutta vertaamalla sitä eräänlaiseen lankavyyhteen, johon keriytynyt lanka on muodostunut toisiinsa punoutuneista säikeistä. Kuten Kuuva kuvaavasti kirjoittaa, "käsityksemme hulluudesta riippuu siitä, mistä kohdin leikkaamme poikki hulluuden langan ja millaisia leikkauskohdasta avautuvia säikeitä lähdemme seuraamaan" (s. 52). Kuuvan lankametafora on inspiroiva, ja se havainnollistaa osuvasti kulttuurisen ajattelun ajallista kerrostuneisuutta: hulluuden langat tulevat jostain ja matkaavat edelleen jonnekin siten, että myös nykypäivänä esitetyt käsitykset rakentuvat punoutuneina menneisyyden säikeisiin.

Rissasen artikkeli käsittelee veden merkityksiä mielisairaanhoidossa. Aineistona toimivat siilinjärveläisen Harjamäen sairaalan arkistoidut potilasasiakirjat sekä entisten hoitajien haastattelut ja kirjoitukset. Artikkeli osoittaa, miten vesi liittyi 1900-luvun alkupuolella esimerkiksi pakkokylpyihin ja näyttäytyi siten psykiatrisena hoitokäytänteenä, mutta sittemmin vesi muuttui lähinnä terapeuttiseksi virkistyksen lähteeksi, josta potilaat pääsivät nauttimaan esimerkiksi veden äärelle suunnattujen retkien myötä.

Artikkelinsa lähtökohtia selittäessään Rissanen kirjoittaa tarkastelevansa veden tematiikkaa antropologi Mary Douglasin (2000) likaan ja puhtauteen liittyvien teoretisointien avulla (s. 86). Douglasin soveltaminen jää artikkelissa kuitenkin vähäiseksi, käytännössä vain yhden ja sellaisenaan varsin pintapuolisen maininnan tasolle (s. 88), eikä tutkija palaa Douglasiin myöskään yhteenvetoluvussa. Kulttuurintutkijan näkökulmasta tämä on harmillista, sillä 
Douglasin teoretisointien soveltaminen sielun ja ruumiin puhtauteen sekä veden tematiikkaan liittyvän aineiston analyysiin olisi avannut aiheeseen kiehtovia näkökulmia: miten tulkita esimerkiksi sitä, että potilaat oli tapana pestä heti sairaalaan saapuessa? Mitä oli se "lika", jota mielisairaista oikeastaan pyrittiin pesemään?

Rissasen artikkelin herättämät kysymykset palautuvat teoksen monitieteisyyteen. Yhtenä perusteena sille, miksi samaan teokseen on istutettu erilaisia tieteenaloja ja näkökulmia edustavia artikkeleita, on toimittajien mukaan ollut pyrkimys tehdä näkyväksi tieteenalan ja menetelmien vaikutus "siihen, mitä ilmiöstä paljastuu ja millaisena hulluus kussakin kontekstissa näyttäytyy" (s. 20). Rissasen artikkelia lukiessa kohtasin tämän varsin konkreettisesti: historiantutkijana Rissanen käsittelee ja lukee aineistoaan toisenlaisin silmälasein kuin kulttuurintutkija, ja myös kuva hulluudesta piirtyy erilaiseksi kuin kulttuurintutkijan käsittelyssä. Molemmat näkökulmat ovat yhtä arvokkaita, mutta erityisen hedelmällistä olisi eri tieteenaloja edustavien tutkijoiden osaamisen yhdistäminen saman aineiston äärellä. Silloin monitieteisyys ja tieteidenvälisyys toteutuisivat parhaalla mahdollisella tavalla. Käsillä olevassa teoksessa jokainen artikkeli on kuitenkin yhden, omaa tieteenalaansa edustavan tutkijan laatima.

\section{Uusia aineistoja, tuoreita näkökulmia}

Useissa artikkeleissa luetaan uudentyyppisiä, aiemmassa tutkimuksessa vähintäänkin niukalti tarkasteltuja aineistoja. Suurin osa - yhteensä seitsemän artikkelia - liittyy jollakin tapaa taiteeseen. Useimmiten taide on tutkimuksen kohde ja aineisto, kuten artikkeleissa, joissa analysoidaan kirjallisuuden hulluustematiikkaa. Toisinaan taide voi kuitenkin olla myös tutkimuksen tekemisen konteksti ja menetelmä, kuten Kirsi Heimosen artikkelissa, jossa tarkastellaan tanssimista julkisilla paikoilla ja siihen liittyvää rajankäyntiä normaaliuden, outouden ja hulluuden välillä.

Heimosen artikkeli on sijoitettu osioon "Hulluus yhteisössä", mutta tämäkin artikkeli eroaa voimakkaasti osion kahdesta muusta, kirjallisuuden hulluustematiikkaa tarkastelevasta tekstistä. Taiteilija-tutkija Heimonen on tanssinut esimerkiksi kirjastoautossa ja työpaikkaruokalassa, ja näiden tanssimisten itsessään ja ympäristössään herättämiä ajatuksia ja tunteita hän pyrkii artikkelissaan purkamaan. Artikkelia lukiessa huomio kiinnittyy erityisesti sen kieleen, joka on kuvailevaa, miltei runollista. Kyseessä on tietoinen, metodinen valinta, jonka avulla Heimonen pyrkii välittämään ja sanallistamaan kokemuksia ja tunteita, joille ei löydy vakiintuneita ilmaisuja ja joiden artikuloiminen on vaikeaa. Tällöin tullaankin lähelle hulluuden olemusta ja ydintä, sillä kuten kirjassakin usein toistetaan, hulluus pakenee selityksiä ja määrityksiä. Lisäksi hulluuden kokemusta on toisinaan kuvattu tilana, jossa yksilö menettää kosketuksensa kieleen ja sitä kautta myös kanssaihmisiin, ja Heimosen artikkeli etsiikin oivaltavasti taiteen ja humanistis-taiteellisen tutkimuksen mahdollisuuksia tämän yhteyden eheyttämiseksi.

Myös Jari K. Kokkisen ja Saara Jäntin artikkeleissa taidetta hyödynnetään rohkeasti. Kokkinen tarkastelee psykoosin kokeneiden ihmisten kertomuksia ja etsii niistä katarttista, toipumiseen johtanutta käännekohtaa. Aineisto on muodostettu kekseliäästi: Kokkinen on koonnut kirjoituksia ja tehnyt syvähaastatteluja, joiden pohjalta hän itse on luonut draamallisia tarinoita psykoosista ja siitä selviämisestä. Jäntti taas pohtii psyykkiseen sairastamiseen liittyviä kodittomuuden kokemuksia. Hän on tehnyt etnografista, mielenterveyskuntoutujien 
asumispalveluyksikköön kohdistunutta tutkimusta, jonka aikana kodittomuutta käsiteltiin paitsi haastatteluissa myös yksikössä toimineessa draamaryhmässä. Samoin kuin Heimosen artikkeli, myös Jäntin ja Kokkisen artikkelit osoittavat tieteen ja taiteen yhteistyön merkityksen erityisesti siinä, miten taide voi auttaa ilmaisemaan muutoin hankalasti sanoitettavan sairauden kokemuksen. Lisäksi molemmat artikkelit tuottavat tarkkanäköisiä huomioita, jotka olisivat hyödynnettävissä mielenterveystyössä ja -politiikassa.

Tiina Katriina Kukkosen artikkelissa aineisto on jo ennalta tuttu ja tutkittu - hän analysoi Aleksis Kiven Seitsemää veljestä (1870) -, mutta aineistoa luetaan uudenlaisesta näkökulmasta. Kukkosen tavoitteena on tarkastella, miten "veljesten ja kyläyhteisön käsitykset ihmisyydestä ja elämänpiiristä muodostavat monenlaisia kulttuurisia käsityksiä hulluudesta" (s. 209). Kiven klassikkoromaanin uudelleentulkinta hulluuden näkökulmasta on ilahduttava, ja tekstissä on runsaasti tarkkanäköisiä tulkintoja. Artikkeli olisi kuitenkin hyötynyt hieman ryhdikkäämmästä rakenteesta, jossa tutkimusaineiston ja -menetelmän esittely erotetaan selkeästi varsinaisesta analyysistä ja tämä osoitetaan myös otsikoiden tasolla (erit. s. 210212). Teoksen artikkelien alun rakenteet ja erityisesti tutkimusaineistojen ja -menetelmien esittelyt ovatkin kauttaaltaan hieman epätasaisia suhteessa toisiinsa: suurimmassa osassa aineisto ja tutkimuksen kulku esitellään asianmukaisesti, mutta erityisesti parin artikkelin kohdalla käytetty tutkimusaineisto selvisi minulle kauttaaltaan vasta lopun aineistolähteistä.

\section{"Hulluus elää meissä ja meidän keskuudessamme"}

Yksi teoksen ansioista on se, että erilaisten aiheidensa, aineistojensa ja näkökulmiensa kirjon myötä teos tulee osoittaneeksi, miten moninaisesta ilmiöstä hulluudessa ja siihen kohdistuvassa tutkimuksessa on kyse. Kuten teoksen jälkisanoissa kauniin kuvaavasti todetaan, "hulluus elää meissä ja meidän keskuudessamme" (s. 336). Kyse ei ole vain piiloisesta ja marginaalisesta, ei vain toisista ja muista, vaan ilmiöstä, joka koskettaa myös meitä.

Erityisesti Antti Malisen artikkeli tuo hulluuden lähemmäs meitä. Artikkeli kytkeytyy kansakunnan historiaan ja traumoihin, sillä siinä tarkastellaan lapsuuden tunnemuistoja, jotka koskevat aikuisten psyykkistä oireilua toisen maailmansodan jälkeen. Tutkimusaineisto koostuu useista muisteluaineistoista, joista keskeisin on muodostettu Suomalaisen Kirjallisuuden Seuran Perheissä jatkunut sota? -muistitietokeruun tuloksista. Muistot ja niiden analyysi liikuttavat ja herättävät ajatuksia. Huomioni kiinnittyi erityisesti niihin harvoihin mutta kuitenkin pariin otteeseen esille nouseviin muistoihin, jotka kohdistuvat miesten sijasta naisten psyykkiseen oireiluun. Sodasta palanneet miehet kärsivät esimerkiksi painajaisunista, mutta sotavuodet olivat kuormittaneet myös naisia, minkä seurauksena esimerkiksi perheenäiti saattoi äkkiä luhistua maahan ja huutaa käsittämättömästi (s. 194). Sotien aikainen ja jälkeinen naisten psyykkinen oireilu on vielä miestenkin oireilua niukemmin tunnettu ja tutkittu aihe, ja erityisesti tästä lukisin Maliselta mielelläni lisääkin.

Yksi hulluuteen kiinteästi liittyvä, itseäni loputtomasti kiehtova piirre on se, että vaikka hulluudessa onkin ensisijaisesti kyse sairauden ja poikkeavuuden määrityksistä, hulluus heijastelee samalla arvoja ja normeja - sitä, mitä on kulloinkin pidetty hyvänä, tavoiteltavana ja odotuksenmukaisena. Tämä hulluuden kaksijakoinen - yhtäältä poikkeavuudesta ja toisaalta normaaliudesta kielivä - ulottuvuus piirtyy esille eritoten Jani Tanskasen artikkelissa, joka on teoksen parhaimmistoa. Sen aineistona on fiktiiviseen maalaisyhteisöön sijoittuva Arto Paasilinnan romaani Ulvova mylläri (1981), jonka päähenkilön yhteisö on määritellyt 
hulluksi. Artikkeli pohtii hulluksi määrittymisen syitä ja käytänteitä osoittaen, miten kyse oli muun muassa yhteisön omista peloista ja epävarmuuksista, jotka se projisoi hulluksi määrittämäänsä yksilöön. Analyysi on monipuolista, ja kirjoittaja kontekstualisoi ja pohtii hulluuden määrittymistä laajalti. Erityiskiitoksen ansaitsee artikkelin suomen kieli, jota on käytetty virheittä ja taitavasti - toisinaan jopa hieman leikitellen mutta pysyen kuitenkin akateemisen kirjoittamisen raameissa. Kieliasun moitteettomuus piirtyy esille suhteessa muihin artikkeleihin, joista osaa vaivaavat kirjoitusvirheet ja oikoluvun puute.

\section{Täyttyivätkö odotukset?}

Jos Hulluus ja kulttuurinen mielenterveystutkimus -teosta tarkastelee puhtaasti perinnetieteellisin silmälasein, on harmillista, että vaikka siinä pyritään monitieteisyyteen ja tieteidenvälisyyteen, sen sivuilla ei juurikaan keskustella perinnetieteellisen tai sen lähialojen, esimerkiksi kulttuuriantropologisen tutkimuksen kanssa. Erityisesti "Hulluus yhteisössä" -osioon sijoitetut Kukkosen ja Tanskasen artikkelit olisivat hyötyneet perinnetieteellisestä kylähulluustutkimuksesta (esim. Saarinen 2003). Myös muista perinneaineistoja ja yhteisöllistä poikkeavuuden sietokykyä tarkastelevista tutkimuksista, kuten Jan Löfströmin teoksesta Sukupuoliero agraarikulttuurissa (1999), olisi löytynyt oivia keskustelukumppaneita.

Korkeiden odotusten voi kuitenkin katsoa täyttyneen, niin monipuolinen, innostava ja toisinaan yllätyksellinenkin teos Hulluus ja kulttuurinen mielenterveystutkimus on. Sisällöltään ja rakenteeltaan se on kyllä hieman hajanainen, sillä artikkelien väliset voimakkaat kontrastit nakertavat tekstien välistä koheesiota ja teoksen yhtenäisyyttä. Toisaalta kuitenkin juuri näkökulmien ja menetelmien kirjavuus tekee teoksesta toimivan keskustelunavauksen ja johdatuksen hulluustutkimuksen ja kulttuurisen mielenterveystutkimuksen ajankohtaisille kentille. Omalla kohdallani teoksen monitieteinen sisältö sekä monipuoliset aineistot ja tulkinnat - erityisesti ne, joissa itse näin mahdollisuuksia myös toisenlaisille lähestymistavoille - auttavat myös terävöittämään oman tutkimukseni paikkaa ja merkitystä hulluustutkimuksen laajalla kentällä. Jokaisella tieteenalalla, näkökulmalla ja menetelmällä on arvokas sijansa pyrittäessä ymmärtämään hulluutta, joka, kuten teoksen jälkisanoissa osuvasti todetaan, jo "lähtökohtaisesti pakenee järkeä ja ymmärrystä" (s. 330).

\section{Kirjallisuus}

Douglas, Mary. (1966) 2000. Puhtaus ja vaara: Ritualistisen rajanvedon analyysi. Tampere: Vastapaino.

Hulluus-teemanumero 2016. Elore 23(1). https://journal.fi/elore/issue/view/5473.

Kinnunen, Anna. 2017. "Ongelmana onania. Itsetyydytyksen mikrotasoiset merkitykset 1930luvun psykiatrisissa sairauskertomuksissa." Elore 24(2): 1-24. https://doi.org/10.30666/ elore.79302

Kivi, Aleksis. 1870. Seitsemän veljestä. Helsinki: Suomalaisen Kirjallisuuden Seura.

Löfström, Jan. 1999. Sukupuoliero agraarikulttuurissa. "Se nyt vaan on semmonen." Helsinki: Suomalaisen Kirjallisuuden Seura.

Maanmieli, Taija Karoliina. 2019. "Häpeä suomalaisten mielisairaalamuistoissa." Elore 26(1): 29-41. https://doi.org/10.30666/elore.79540 
Paasilinna, Arto. 1981. Ulvova mylläri. Helsinki: WSOY.

Saarinen, Tuija. 2003. Poikkeusyksilö ja kyläyhteisö. Tutkimus Heikan Jussin (Juho Mäkäräisen) elämästä ja huumorista. Helsinki: Suomalaisen Kirjallisuuden Seura.

FM Anna Kinnunen valmistelee Itä-Suomen yliopistossa perinteentutkimuksen väitöskirjaa mielen sairauteen kytkeytyvistä kulttuurisista käsityksistä. 